palpus, borne on a distinct, swollen, palpifer, is long and 4-segmented. The labrum-epipharynx (fig. I I A, l.ep.) is short and well chitinized. The hypopharynx is short and pointed.

Stygeropis sp. This genus has the mouthparts in the same general condition as Holorusia. The maxillae however present no trace of lobes. The paraglossae of the labium are fused for about half their length, are heavily chitinized at the outer margins and have pseudo-tracheae, of the character of those in Holorusia, namely a few large main trunks, and numerous small, inconspicuous, delicate, transversal ones. Tipula sp. In Tipula (fig. II, B, li) the fusion of the paraglossae extends farther and the system of pseudotracheae is better developed, the transversal ones being larger and more disrinct than in Holorusia.

The mouthparts of the Tipulidae are borne at the anterior extremity of an anterior prolongation of the head capsule. The mouthparts themselves are not elongated ; the maxillary palpi, however, are especially longer and slender.

\title{
A NEW LITHOSIAN.
}

BY HARRISON G. DYAR, WASHINGTON, D. C.

Ozodania n. gen. - Head prominent, tongue distinct, coiled; male antennae simple; no ocelli. Palpi slender, upturned, reaching to middle of front; legs moderate, hind tibiae with four spurs. Fore wings slightly over twice as long as broad; 12 veins, 7 to 9 stalked, the rest from the cell; hind wings with vein 2 remote from 3 the rest evenly spaced, 6 and 7 stalked, 8 joining the subcostal for two-thirds the length of the cell; outer margin excavate, the anal angle produced; anal hairs of male conspicuous but not reaching the end of the body.

Type the following:-

Ozodania schwarziorum n. sp. - Fore wing blackish lead color, a broad upright orange yellow band resting on the lobe at inner angle where the color becomes crimson; a similar stripe along internal margin, scarcely attaining the upright band, touched with crimson at base. Hind wings reddish pink, costal margin yellowish, a minute or distinct leaden apical band. Thorax gray; vertex of head, collar and patagia orange yellow abdomen pinkish red; legs gray and yellowish. Wings below with the gray ground color more or less replaced by reddish. In the Arizona specimen the gray parts are as on the upper side, but the pale parts red and broader; in the Mexican specimen the gray is reduced to a small apical and basal patch on fore wings and is absent on hind wings. Expanse $16 \mathrm{~mm}$.

Two males, Oracle, Arizona (E. A. Schwarz); Rancho Hannover, State of Vera Cruz, Mexico (H. Schwarz). U. S. National Museum, type number 4102 .

This genus stands between Cisthene and Odozana. From the former it differs in the form of the hind wings and a slight enlargement on the outer angle of fore wings; from the latter, in the very slight development of the anal hairs and in the longer palpi (Walker says those of Odozana are porrect and do not exceed the head).

This species must have been taken in 
Mexico before. I can only account for its absence from the Biologia Cent.-Amer. by supposing that it has been confounded with Cisthene unifascia, which it greatly resembles in markings.

\section{ALEURODICUS MIRABILIS.}

Aleurodes mirabilis Ckll., Psyche, June I898, p. 225. Prof. C. H. T. Townsend found this species in quantity at Minatitlan, Mexico, April 25, I898, on the under side of Anona leaves. Fortunately, he secured a single $\delta$ adult, which shows that the insect belongs to Aleurodicus. The anterior wings are slightly over $2 \mathrm{~mm}$. long, and about $\mathrm{I} \frac{1}{3}$ $\mathrm{mm}$. broad; white, with two very pale grey bands; the first crossing the wing just before the fork of the median vein, but interrupted for a space below the vein; the second a dilute transverse cloud not far from the apex of the wing. Body about $2 \mathrm{~mm}$. long, exclusive of the forceps, which is about $\frac{3}{4 m}$. Color of body and legs very pale yellow; base of abdomen white; thorax between wings light orange. Antennae orange at the middle. Eyes pale greenish, not divided. Easily known from $A$. anonae Morgan, by the markings on the wings of the adult, and the lingua longer than the sperculum in the pupa.

\section{T. D. A. Cockerell.}

\section{PROCEEDINGS OF THE CLUB.}

I3 January, i899 (cont.). Mr. J. W. Folsom said that Isotoma besselsii Pack. had not been recorded since its original description from specimens found in 1872 by the "Polaris" expedition in lat. $8 \mathrm{I}^{\circ} 2 \mathrm{O}^{\prime}-8 \mathrm{I}^{\circ}$ $5 \mathrm{o}^{\prime} \mathrm{N}$., but that he had found this interesting collembolan in abundance last October on our own coast, occurring in large colonies under stones between tide-marks. Mr. Folsom added that his examples of this well. marked species agree perfectly with Packard's types, which he had already studied through the courtesy of the U. S. National Museum. A discussion followed as to the probable influence of ocean currents in disseminating maritime species.

Guide to the Genera and Classification of the Orthoptera of North America north of Mexico. By Samuel H. Scudder. $90 \mathrm{pp} .8^{\circ}$.

Contains keys for the determination of the higher groups as well as the (nearly 200) genera of our Orthoptera, with full bibliographical aids to further study. Sent by mail on receipt of price $(\$ 1.00)$.

E. W. Wheeler, 3o Boylston Street, Cambridge, Mass.

\section{A. SMITH \& SONS, 269 PEARL STREET, New York.}

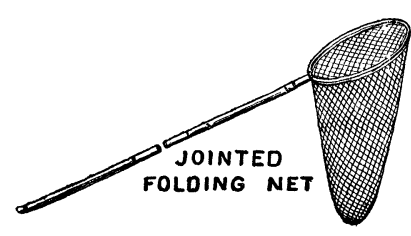

GOODS FOR EMTOMOLOGISTS,

Klaeger and Carlsbad Insect Pins, Setting Boards, Folding Nets, Locality and Special Labels, Forceps, Sheet Cork, Eic. Other articles are being added, Send for List. 

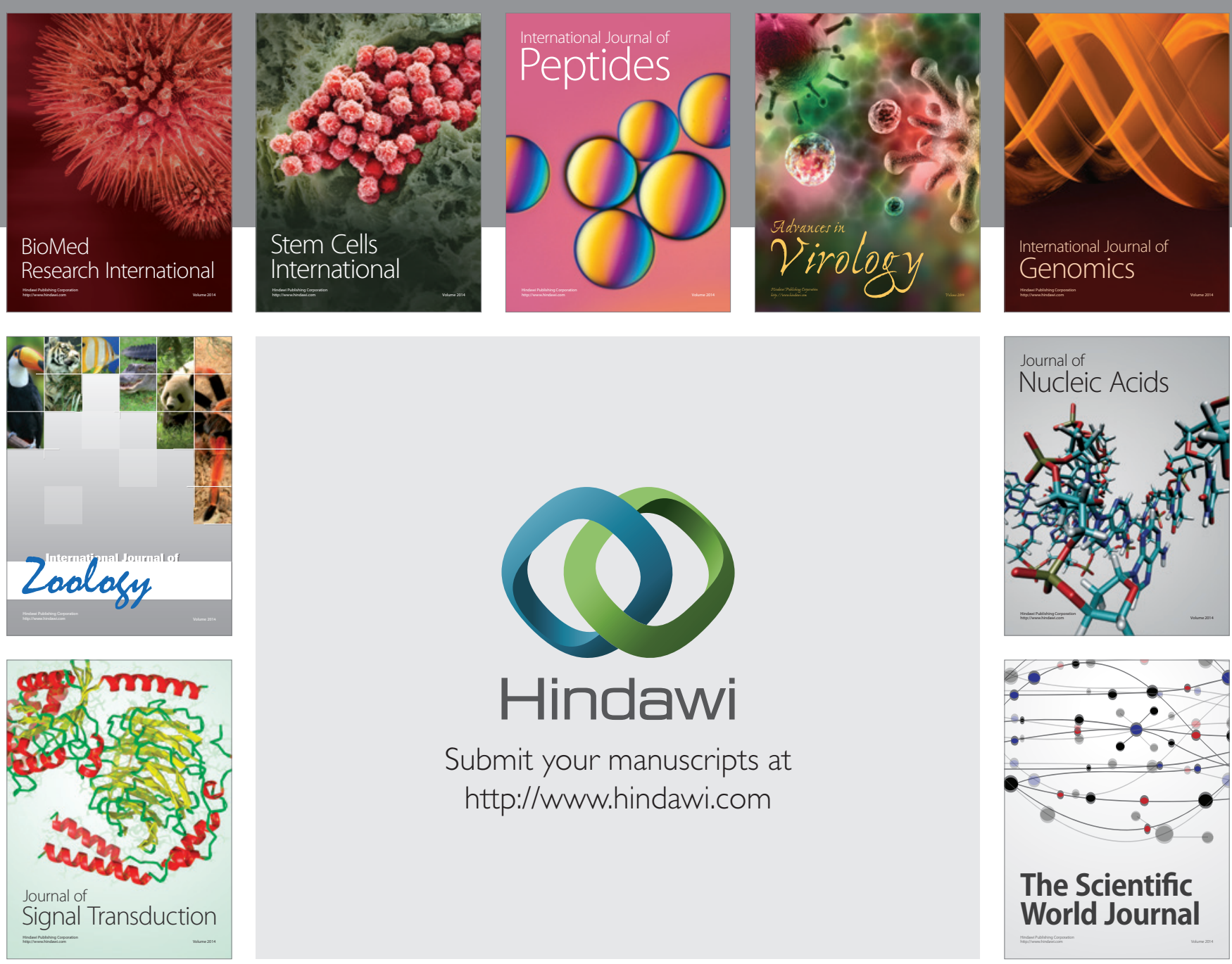

Submit your manuscripts at

http://www.hindawi.com
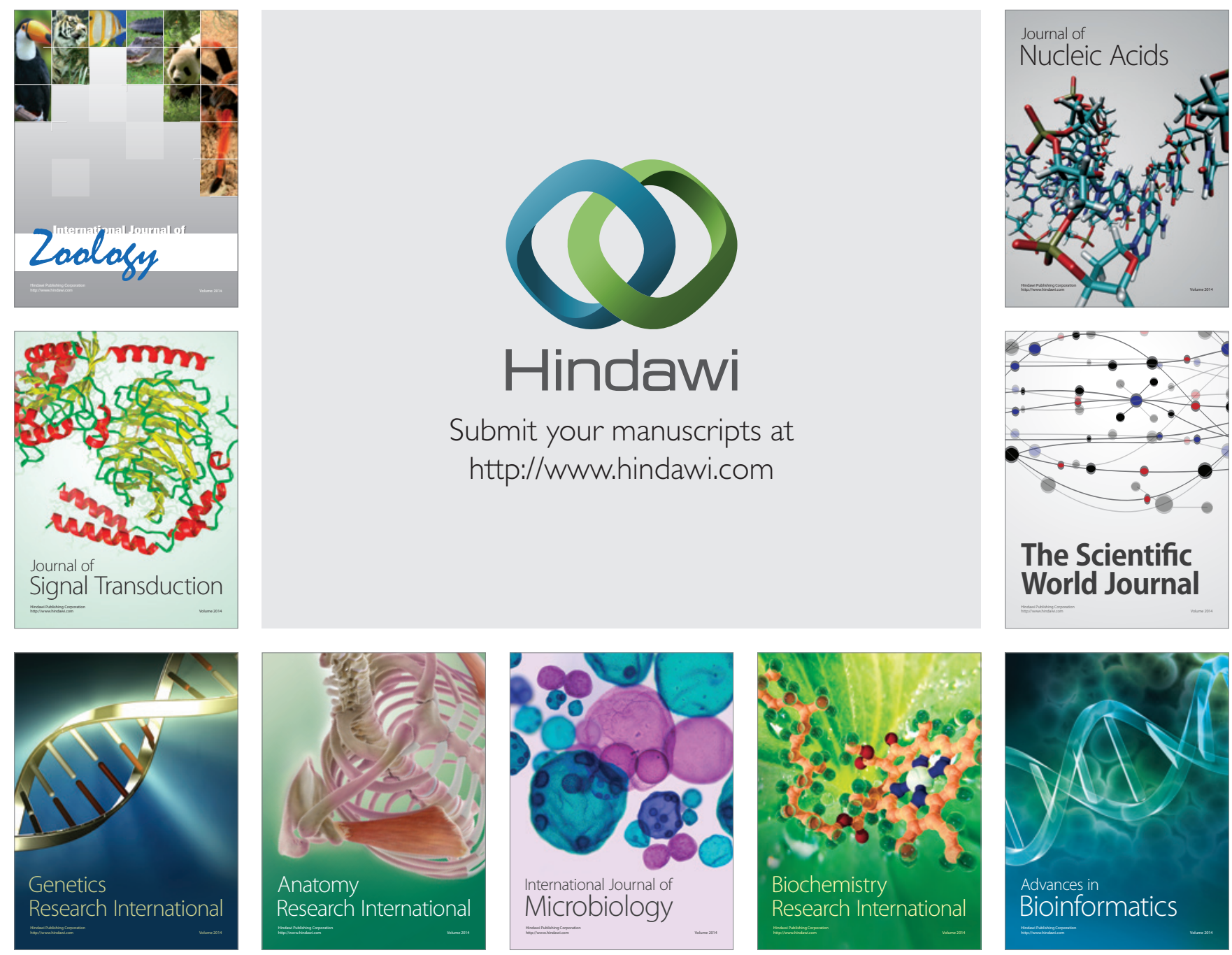

The Scientific World Journal
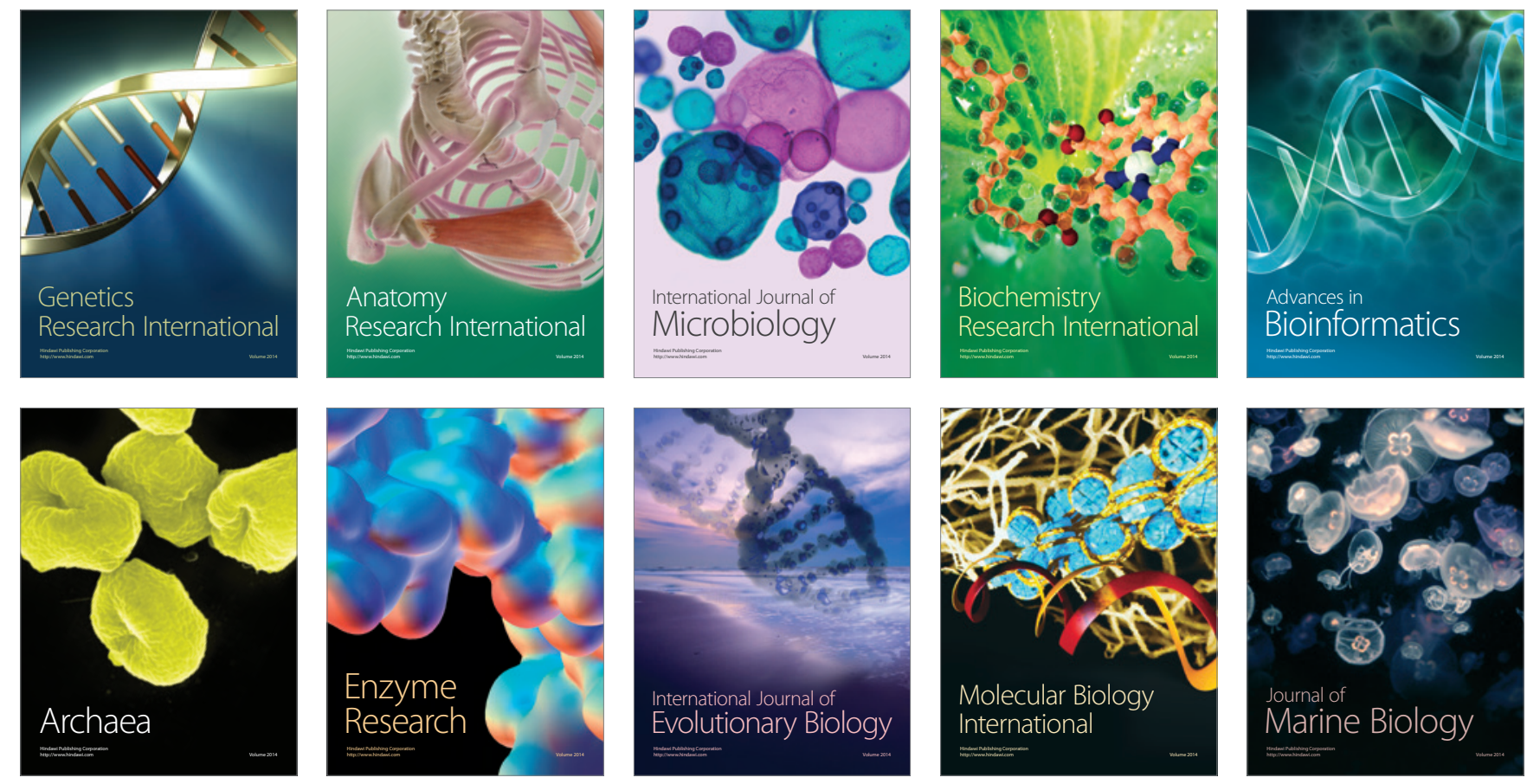